\title{
Tres medici, duo athei? The physician as atheist and the medicalization of the soul
}

\author{
Charles T. Wolfe (Centre for History of Science, Dept. of Philosophy and Moral Sciences, Ghent \\ University, charles.wolfe@ugent.be)
}

\begin{abstract}
Until recently, scholars examining the historical contexts and evolution of the 'mind-body problem' paid only cursory attention to its specifically medical context, if at all. At best, some 'folk physiology' was entertained, usually to laugh at it (the pineal gland, animal spirits). Conversely, historians of neuroscience or of artificial intelligence (Jeannerod 1985, Dupuy 2000) often present La Mettrie as a heroic early figure whose medical practice somehow provided the empirical, naturalistic basis for his materialist metaphysics: their symmetrically inverse mistake is to take professions of medical authority too literally (although there are genuine cases where all of the above does coalesce, such Hieronymus Gaub's reflections on the 'regimen of the mind' in the mid-eighteenth century, or, more theoretically, Guillaume Lamy's Epicurean-inflected Anatomical Discourses on the Soul, eighty years earlier).Contrary to the denial of the relevance of medicine in early modern philosophy, it seems patent to me, on issues such as the body-soul (then body-mind) relation among others, that it is very hard to separate medical theory, medically nourished philosophical speculation, and metaphysics. This is the case, whether in Descartes, Gaub, the 'animist' Georg-Ernest Stahl, or materialists such as Guillaume Lamy and La Mettrie: medicine, or rather 'a certain idea of medicine', is everywhere.

Here I focus on the motif of a radical medicine - a medical precursor of the Radical Enlightenment (Israel 2001, 2006, 2007), symbolized by the slogan, tres medici, duo athei: medicine as a basis for atheism. This theme runs through various works of medical or medicotheological propaganda: Thomas Browne's 1643 De religio medici begins with Browne regretting rumors of doctors being atheists as the "general scandal of my Profession"; Germain de Bezançon's 1677 Les médecins à la censure works hard at rebutting the saying, "Bon Physicien, mauvais chrétien." But these are examples of the fear of a radical medicine - a medicine that denies the existence of an immortal soul, or even defends materialism and atheism. Are there positive statements of this doctrine? Indeed, attacks on it are much more common than statements identifying with it, like medical versions of natural theology in general.

In fact, just as there were theologically motivated medical works, there were also medically motivated works of radical or heretical theology, like William Coward's Second Thoughts on the Human Soul (Coward 1702, building on Overton 1644), which engaged in polemics concerning the nature of the soul - mortal or immortal? (Thomson 2008). Parallel to the mortalist trend, but flowing into a common genre of radical, medico-materialist texts (sometimes anonymous, such as L'Âme Matérielle, from the 1720s) are at least two other strands of radical medicine: a post-Cartesian focus on medicina mentis and the nature of the mind (Henricus Regius, Hieronymus Gaub, Antoine Le Camus), and an Epicurean medicine, in which mind and body are organismically united, with an additional hedonistic component, notably in Lamy, Mandeville
\end{abstract}


and La Mettrie (Wright 1991, Wolfe and van Esveld forthcoming 2014). The focus on a medicine of the mind (Corneanu, ms. 2013) is obviously connected to a 'medicalization of the soul': there was a body-soul problem in and for medicine, growing out of some of the medicalization of 'pneumatology' in natural philosophy. Radical medicine is located somewhere in between the early forms of 'naturalization' or 'medicalization' of the soul and the pose of scientific neutrality that is characteristic of early nineteenth-century medicine (as in Cabanis, Bichat or Bernard): it is a short-lived episode. My concern is not to identify physicians who were atheists but to seek to define this intellectual context, in which mortalist, post-Cartesian and Epicurean strands intersect and sometimes come together. I suggest that medically influenced materialism in the Radical Enlightenment (e.g. in the later French cases, La Mettrie, Ménuret and Diderot), is different from later, more experimentally focused and more quantitatively oriented forms of medical materialism, precisely because of its radical dimension. This radical medicine often insists on vitality, as opposed to "anatomie cadavérique": it is vital and hedonistic, a medicine for pleasure.

Keywords: radical Enlightenment, heterodoxy, medical materialism, mortalism, atheism, soul

With us there was a doctor of Physic ... Well read was he in Esculapius, and ... Hippocrates, Galen ... Serapion, Rhazes, and Avicen, Averrhoes, Gilbert, and Constantine, Bernard and Gatisden, and John Damascene. ... It's no libel / To say he read but little in the Bible. (Chaucer 1933, Prologue, I. 411-438)

medicus est physicus sensualis (Bezançon 1677, 335)

I.

The interrelation between the genres, discourses or practico-conceptual clusters called 'medicine' and 'philosophy' in early modernity is more apparent now than it was even ten years ago. A number of interesting works have appeared which demonstrate in diverse ways, bristling with erudition, that we ignore this interrelation - and thus all sorts of 'contamination' of apparently neutral, austere metaphysics by messy, fluid, embodied discourse, from animal spirits, fermentation, mental pathology and fevers (notably in the work of Thomas Willis: Willis 1659/1681, Willis 1684), to venery or vertigo (e.g. La Mettrie's 1737 Traité du vertige) - at our 
peril. ${ }^{1}$ Much as Katharine Park and Lorraine Daston noted, with a degree of insider humour, that unlike their classmates in the 1970s, when they opened works of early modern philosophy, they saw monsters everywhere (Park and Daston 1998, 9), I observe that, contrary to the standpoint of scholars of early modern philosophy who sometimes go out of their way to deny that medicine could have played a role, even a constitutive role, in classic metaphysical debates (Garber 1998, citing Henry 1989), it seems patent to me, on issues such as the body-soul (then body-mind) relation among others, that it is very hard to separate medical theory, medically nourished philosophical speculation, and metaphysics. This is the case, whether in Descartes, in the 'animist' Georg-Ernest Stahl, or materialists such as Guillaume Lamy and La Mettrie: medicine is everywhere, certainly in materialist and other heterodox approaches to body-soul and body-mind relations (Thomson 2008). Not only are medical doctrines cited for philosophical purposes (and 'physician-philosophers', médecins-philosophes, were eager to intervene in quarrels of the former sort); the reconstruction of the genesis of what we understand as pure philosophical doctrines sometimes reveals explicitly medical elements therein. We witness a significant interplay in this period between physicians, natural philosophers, and medically 'influenced' philosophers - both physicians writing 'philosophy', like Guillaume Lamy and Abraham Gaultier, in his 1714 Parité de la vie et de la mort (Réponse à un théologien) ${ }^{2}$, but also Bernard Mandeville, in his Treatise of the Hypochondriack and Hysterick Diseases (1711, revised 1730); physicians who become philosophers, like La Mettrie; and philosophers whose career reflects a continuous engagement with developments in medicine and physiology, like Diderot, for whom "there are no works I read with more pleasure than medical works" (Diderot 1975-, XVII, 510).

This is patent in the case of debates on the status of the soul: mortal or immortal? material or immaterial? Beginning in the late Renaissance and gathering momentum in the sixteenth and seventeenth centuries, there is a clear sense in some authors, not that medical observations e.g. at patients' deathbeds, necessarily 'prove' materialism, but rather, the slightly weaker and more flexible claim that physicians have a special kind of expertise in dealing with matters concerning body and soul. As Rob Illife put it suggestively, "In an important sense, the soul - its location and its function as the active and moral essence of the individual - should be seen as the product of . . . forensic and physiological knowledge" (Iliffe 1995, 434). From the medical mortalists in late seventeenth-century England (including William Coward, discussed in

\footnotetext{
${ }^{1}$ For instance, Smith, ed. 2006; Thomson 2008; Wolfe and Gal eds., 2010.

${ }^{2}$ It is thanks to Olivier Bloch that we are familiar with the work of the physician Abraham Gaultier, a Protestant turned atheist, and author of an 'epigenetic materialist' treatise (Gaultier 1714/1993) that derives some of its ideas from Lamy and Harvey (his materialist reading of epigenesis is not without recalling Diderot's later articulation of epigenesis and Spinozism (Wolfe 2014), although ironically, Gaultier denounces Spinoza as well as Descartes and Malebranche as metaphysicians, even though the subtitle of his work includes the statement that "Life and Death are ... modifications of one Substance"). Gaultier's original work was almost entirely unknown, but large portions of it were excerpted in a clandestine manuscript entitled Parité de la vie et de la mort, which did circulate.
} 
Thomson 2008) to Guillaume Lamy's Anatomical Discourses (1675, revised 1679) and Mechanical and Physical Explanation of the Functions of the Sensitive Soul (1677), and in the eighteenth century, La Mettrie's Natural History of the Soul (1745), to which we could add some of the medical entries in the Encyclopédie by the Montpellier physician Jean-Joseph Ménuret de Chambaud (e.g. the entry on Death, "Mort," 1765), medicine matters very much in the approach to and construction of the problem of the soul. ${ }^{3}$

This connection between medicine and a traditional metaphysical problem could be articulated on the basis of varying historical sources: it could stem from late AristotelianAverroist discourses on 'the organic soul' or the soul as 'life principle', as in Pomponazzi or, more classically, it could build on Galen's treatise Quod animi mores, on the soul's dependence on the body. For here, Galen had argued that "it is preferable to say . . . that the mortal part of the soul is the mixture of the body" (Galen 1997, 153, 157); even if there were a "separate substance" for the soul, it would still be dependent on ("a slave to") the mixtures of the body (155). That is, given the presence of these various humoral mixtures in any part of our body, the soul "cannot but be a slave to the body." While Galen himself did not make any overt philosophically reductionist claims (as distinct from a medically reductionist account), in an early modern context these ideas, whether directly quoted or modified, could sound quite different, as in the Gassendist François Bernier's suggestion that "it would appear that Galen was persuaded the Soul was a spirit that emerged out of the blood" (Bernier 1678, vol. V, 452). ${ }^{4}$

With some reservations, also because these contexts do not lend themselves to an overall theoretical 'systematization', one can say that there was a body-soul problem in and for medicine, growing out of some of the medicalization of 'pneumatology' in natural philosophy. This is not restricted to, or explainable in terms of any particular medical tradition exclusively (the invocation of Galen's Quod animi mores fuels one strain of physicians claiming authority on the question of body-soul relations, but Cartesian-inspired physicians from Regius to Boerhaave and Gaub do so as well, as do 'Epicurean' physicians like Lamy). In that sense, historians of philosophy claiming that medicine is irrelevant to early modern disputes on atheism or the status of the soul, which are purely metaphysical (Henry 1989, 92-93; Garber 1998, 764), would be well advised to leaf through any of the writings of the above-mentioned physicians. It would be harder then to claim that (here with the specific case of England) physicians "failed to make a

\footnotetext{
${ }^{3}$ On Lamy see Thomson 1992 and Anna Minerbi Belgrado's extensive and extremely informative introduction to her edition of Lamy's Discours anatomiques \& Explication méchanique et physique des fonctions de l'âme sensitive (Lamy 1996), as well as the section on Lamy in Wolfe and van Esveld forthcoming. On Ménuret see Rey 2000a and Wolfe and Terada 2008.

4 See generally Bernier 1678, vol. V, book VI, ch. iii: "What the animal soul is." Laurentius (Du Laurens) in his 1597, argues vehemently against Galen for having a 'deterministic' vision of the functioning of body-soul interaction. Bezançon's sentiment is that we should not follow Galen in everything: "that he was nourished in the darkness of paganism, and consequently was not enlightened by the heavenly rays of faith, is his own personal misfortune" (Bezançon 1677, 330).
} 
substantial contribution ... on the propagation and spread of radical ideas between 1660 and 1700" (Elmer 2007, 225); or that "The proverbial atheist, the physician, hardly appears at all in learned attacks on atheism," because "mechanist versions of atheism drew all the fire" (Henry $1989,91)$. This would have been news to anyone reacting to provocative claims concerning the mortality of the soul, some of which emanated from physicians claiming a medical 'foundation' for such claims, e.g. William Coward's Second Thoughts on the Human Soul (Coward 1702). There are actually many examples of this - to pick one, Thomas Browne, in his 1643 De religio medici, alludes to precisely the 'wrong' sort of influence Galen could have: "I remember a Doctor in Physick, of Italy, who could not perfectly believe the immortality of the soul, because Galen seemed to make a doubt thereof" (Browne 1892, § XXI, 45). ${ }^{5}$

That physicians played a prominent role in challenges to body-soul dualism, or could be quoted and used, sometimes liberally, in reductive materialist arguments (most characteristically in La Mettrie: Wolfe 2009) is itself an outgrowth of a much more general and amorphous cultural 'construct': the physician as atheist (Kocher 1947, Mothu 2010). Examples of the latter abound, but I shall mention just a few. At least as early as John of Salisbury's 1156 Polycratus, the warning was heard that physicians "encroached" on the territory of religion:

Physicians however, placing undue emphasis upon nature, in general encroach upon the rights of the author of nature by their opposition to faith. I am not accusing all of them of error although I have heard very many of them arguing about the soul, virtue and its works, growth and decay of body, the resurrection of the same, and creation in a manner contrary to the tenets of faith (John of Salisbury, cit. Kocher 1947, 232-233).

With more gentle irony, Chaucer, in the Canterbury Tales (published gradually during the later fourteenth century), warns regarding the "Doctour of Phisike" that "His study was but little on the Bible" (Chaucer 1933, Prologue, portrait, I. 440). In early modern Europe, accusations that physicians were atheists - that they favoured Hippocrates or Galen over the revealed Word of God - were common. Alain Mothu mentions the anecdote of the thirteenth-century French king, Saint Louis, who is said to have healed a physician of the sickness of atheism, "body and soul," by extracting through the nose a "putrid humor" preventing the physician from "knowing his Maker"; and the Scottish physician Marc Duncan, who taught philosophy at the Protestant

\footnotetext{
${ }^{5}$ Of course, one should not confuse the interpenetration of medicine with metaphysics (something of an auberge espagnole, where many tendencies coexisted and evolved: see Edwards 2012 on how anatomical material was present even in the "scholastic philosophical mainstream" [44]; he speaks of the relation between anatomical studies and the soul as like "cross-border traffic," 46), with the more specific case of an atheist medicine, that is, a type of argument and/or rhetorical figure in which a certain idea of medicine was made to (a) play a role traditionally devolved to metaphysics or (b) have a deflationary impact on traditional metaphysics, notably as regards the soul (Illife 1995). But both of these (the general and the specific forms) run counter to assertions in Henry 1989 and Garber 1998 regarding the distance between medicine and metaphysics.
} 
academy at Saumur in the first third of the seventeenth century, was credited with a witticism that was widely quoted, according to which the physician is animal incombustibile propter religionem, a modern rendering of which might be that the physician is not soluble in religion (Mothu 2010, 317-318, 319).

One factor in these accusations was the figure of the physician as enemy of superstition, including demonic possession: the critique of superstition could of course slide into the critique of specifically Christian superstition. The Constitution of the Society of Jesus (the Order of the Jesuits), written in 1558, forbids the study of medicine, and the study of law, as neither of these was seen as contributing to the ultimate goal of Jesuit study, the glory of God (Edwards 2012, 56). Mothu mentions the case that can serve as indicative of many others, of one Saporta, a Montpellier physician who in 1608 gave a speech "to prove that in Lazarus's resurrection, there was no miracle" (Mothu 2010, 324). This tension between religion and medicine traces back to the doctrine of original sin (Epistle to Romans, V, 12), from which death and by extension all forms of bodily corruption flow. Augustine and others taught, famously, that it was first and foremost the soul that had to be healed, in order to heal all other disorders. And the greatest healer of all was, of course, Christ, 'Christus medicus'; as the physician Germain de Bezançon puts it in his interesting 1677 work Les Médecins à la censure ou Entretiens sur la médecine, "it is God who properly heals, not the physician" (Bezançon 1677, 30). Clerics were prominently represented on the faculty of medical schools until the turn of the sixteenth century (see also the impressive list in Bezançon 1677, 351-353 of prominent physicians who were also clerics). Indeed, faced with this situation there was a real need to defend the ethical legitimacy of calling for a doctor when sick. ${ }^{6}$

The figure of the physician as atheist runs through various works of seventeenth- and eighteenth-century medicine or medico-theological propaganda: Browne's De religio medici begins with him regretting rumors of doctors being atheists as the "general scandal of my Profession" (Browne 1892, $\S \mathrm{I}, 1$ ) and he expected his book would improve this bad image of the medical profession"; a 1707 issue of the London Weekly Comedy claimed that "Physicians are ... generally accounted Atheists" (Porter 2001, 296 n. 39), a concern that also motivates

\footnotetext{
${ }^{6}$ Maria Conforti observes that most histories of medicine written between the sixteenth and eighteenth centuries make no mention of the Christian religion, not even to gesture towards the relation between illness and original sin (Conforti 2007, 77). One can add that histories of medicine written in the past two centuries never mention the atheist motif, perhaps also because they were usually written by physicians who did not desire to highlight the more controversial aspects of their profession.

${ }^{7}$ Ironically, Browne's project backfired in various ways, both in England and on the Continent, where his book was at times equated, sadly for its author, with skepticism or even atheism, and ended up on the Index. Some commentators, including even Pierre Bayle, joked that rather than 'religio medici', the religion of the physician, the book was more of a 'medicus religionis' or 'médecin de la religion', the work of a physician thinking himself above religion (Bayle 1740, IV, 646; Mothu 2010, 324, 330). On the 'religio medici' theme more generally see Cunningham and Grell eds. 1996).
} 
Bezançon's Les Médecins à la censure, a dialogue partly in defense of medicine including its 'ethical' character (part VIII is devoted to a defence of the 'religio medici', or at least to addressing the question, 'are medicine and Christianity compatible?' [338]); the influential cleric and natural philosopher Marin Mersenne devoted an entire chapter of his 1624 L'Impiété des déistes, athées et libertins de ce temps (I, ch. VI) to discussing and rebutting the charge that physicians were atheists, including by an appeal to Galen (Mothu 2010 observes that Mersenne earlier had denounced physicians as potential atheists, so this is something of a reversal; but in the second part of the 1624 work, Mersenne adds that not all physicians are decent individuals; some are libertines, servants of the devil who corrupt women, and so on). These concerns are also at work in varied works of 'medical natural theology', like Philippe Hecquet's 1733 Médecine théologique, which has the explicit subtitle: La Médecine créée, telle qu'elle se fait voir ici, sortie des mains de Dieu (Hecquet 1733; on Hecquet see Brockliss 1989).

In Les Médecins à la censure, Bezançon, through the voice of the character Cariste, a cleric and lawyer who is hostile to medicine (as per the 'Avertissement'), reflects more specifically on the psychological processes at work as physicians become detached from 'fundamentals' (including the existence of design in the universe and thus a Designer-God), in their practice of their profession. Physicians in their professional activity focus so much on 'sensibles' that their minds become accustomed to merely grasping "crude ideas of bodies," as they deny anything supernatural, since flesh and blood do not reveal it. Here a Hippocratic motif is impugned: these physicians explain everything on the basis of 'temperaments', body and matter, and are thus at best proto-materialists (if not materialists outright). In an intriguing turn of phrase, Bezançon says these physicians are justified in calling themselves "sensual physicians": medicus est physicus sensualis (Bezançon 1677, $8^{\text {th }}$ dialogue, 334-335). Physicians have always had a strong "antipathy towards religion," in his view (329). But what is it to be a 'sensual physician'? We can surmise it is something like being an empiricist - not an 'empirick' but the type of thinker who relies on the evidence of the senses. Indeed, when Bezançon glosses on the phrase 'sensual physicians' a few pages later (339), he confirms that it means physicians who fully rely on causes derived from sensation (one can also point to the presence of the empiricist slogan, 'nihil est in intellectu quod non fuerit in sensu' in a variety of medical texts of the period, from Harvey and Sylvius to Mandeville and Ménuret, which has been discussed elsewhere: Cranefield 1970, Wolfe 2010). Indeed, Ménuret de Chambaud, who I have mentioned, uses almost the same phrase, but in a positive sense, in his entry "Mort" in the Encyclopédie:

The separation of the soul from the body, a mystery which may be even more incomprehensible than its union, is a theological dogma certified by religion, and consequently is uncontestable. But it is in no way in agreement with the lights of reason, nor is it based on any medical observation; hence we will not mention it 
in this purely medical article, in which we will restrict ourselves to describing the changes of the body, which, as they alone fall under the senses, can be grasped by the physicians, those sensual artisans, sensuales artifices (Ménuret de Chambaud 1765/1966, 718b).

A "purely medical article" should restrict itself to dealing with changes in the body that "fall under the senses" and thereby can be grasped (especially) by physicians, who are sensuales artifices, craftsmen dealing with the sensory world of bodies. So, reflecting on this and the above cases: the physician is a potential atheist, a proto-materialist, and (more than either of these), a kind of empiricist.

Elsewhere, I have examined aspects of this medico-philosophical doublet with respect to the idea of medical empiricism (Wolfe 2010), the 'material soul' as in part a medical construct (Wolfe and van Esveld forthcoming), or the project of a 'medical Epicureanism' in La Mettrie (Wolfe 2009). Here, my concern is with the specifically radical motif: the idea of a radical medicine - a kind of medical precursor but also actor of the Radical Enlightenment, as noted by Jonathan Israel (Israel 2001). He notes the presence of physicians in his 'Spinozist' narrative, although here (and also in Israel 2006 and 2007) he runs the risk of overstating or taking too literally the implication that, e.g., members of Spinoza's circles such as van den Enden, Meyer and, differently, Adrian Koerbagh were all physicians: what is overstated is the specifically medical dimension. It is not clear that any of these figures, and certainly not Spinoza himself, emphasize either the atheistic or otherwise radical implications of medicine. This radical figure of medicine was symbolized by the slogan, tres medici, duo athei (a shortened version of ubi tres medici, ibi duo athei, or Ubi sunt tres medici ibi sunt duo athei ${ }^{8}$ ), a variant of which was "Bon Physicien, mauvais chrétien" (Busson 1948, 144). La Mettrie will quote the formula tres Medici, duo Athei, ironically (in Les animaux plus que machines, in La Mettrie 1987, I, 328). He also declared, in a kind of mock warning: "the first years of medical study are the first step leading physicians towards irreligion" (La Mettrie 1749, I, 255).

But most often these expressions (the non-ironic ones) are instances of the fear of a radical medicine - a medicine that denies the existence of an immortal soul, or even defends

\footnotetext{
${ }^{8}$ White 1898, II, ch. vii, citing the bull of Pius V (Bullarium Romanum, ed. Gaude, Naples, 1882, VII, 430, 431); Nutton 2001, 32. Sometimes it was presented as a positive claim, e.g. 'radicals' like Vanini were said to claim happily that philosophers and physicians were generally atheists: in his influential attack on free-thinkers, the 1623 Doctrine curieuse des beaux esprits de ce temps, the Jesuit François Garasse took Vanini as a target for this reason: "the miserable Vanini, a charlatan by profession and . . . an atheist in religion, tried to show both by example and in his wicked doctrine, that philosophers and physicians are ordinarily atheists"; Garasse retorted that we know many "able physicians who are even better Catholics," "wholeheartedly so" (Garasse 1623, III, § 9, 255-256). Among other notorious examples, Rabelais himself, something of a father figure for libertines, free-thinkers and other defenders of heterodoxy, was a practicing physician, including at the Hôtel-Dieu between 1532 and 1534 . For more on these accusations of atheism specifically in the English context, see Kocher 1947.
} 
materialism and atheism. Attacks on this doctrine are vastly more common (like medical versions of natural theology in general) than statements identifying with it. Where are we to find positive statements of this doctrine?

In fact, just as there were theologically motivated medical works like Browne's Religio medici or better, Hecquet's Médecine théologique, there were also medically motivated works of radical or heretical theology, like Coward's Second Thoughts on the Human Soul, which engaged in polemics concerning the nature of the soul - mortal or immortal? (Thomson 2008). Mortalism was a recognized heresy, the view that the universe is entirely material, and the soul is as mortal as the body, sometimes on the definition that the soul is just a mode of the body ... yet this universe is nevertheless a divine creation. Mortalists generally held that the word (and idea) of an immortal soul was a Catholic invention, nowhere to be found in Scripture. The most intriguing brand of mortalism for the present discussion was that professed by some English physicians in the late seventeenth and early eighteenth centuries (from Richard Overton's Man's Mortality, 1644 to Coward's Second Thoughts on the Human Soul, 1702), who felt that their medical expertise, specifically at patients' deathbeds, gave them the authority to state that the soul died with the body. As Mandeville, himself a practicing physician, put it, "Nor is it clashing with Christianity to affirm ... that Man is wholly mortal. . . The Resurrection of the same person ... must necessarily include the Restitution of Consciousness" (Mandeville $1711 / 1730,51)$. The additional medical emphasis of Coward and others was to claim an empirical foundation for the mortality of the soul, which dies with the body (or 'sleeps' depending on the theological variants), until resurrection on the day of the Last Judgment. Sometimes it was additionally argued that the soul has been mortal ever since the Fall ...

Parallel to the mortalist trend, but flowing into a common genre of radical, medicomaterialist texts (sometimes anonymous, such as L'âme matérielle, from the 1720s) are at least two other strands of radical medicine: one we might term a post-Cartesian focus on medicina mentis and the nature of the mind (Henricus Regius, Hieronymus Gaub, Antoine Le Camus), and the other an Epicurean medicine, in which mind and body are united, but the vision of organism is also one which emphasises a hedonistic motivational process, notably in Lamy, Mandeville and La Mettrie (Wright 1991, Wolfe and van Esveld forthcoming 2014). In both cases, medicine has a rhetorical dimension tailored to lend support to various kinds of heterodoxy or radicalism, whether these are presented as overtly atheist or not.

I shall discuss each in turn before turning to the way these discourses of a 'medical atheism' end up in the service of a materialization of the soul.

II. 
The post-Cartesian strand and the Epicurean strand appear relatively distinct if we consider some representative seventeenth- and early eighteenth-century figures, but they were also sometimes combined, as in the case of Cyrano de Bergerac's physics and cosmology, or La Mettrie's idea of the man-machine (Wolfe 2004), or, more germane to the present essay, the theme of a 'materialization of the soul'. But first I shall quickly examine the Cartesian and the Epicurean elements (or 'players') in turn.

On the Cartesian side (increasingly broadly construed as a mechanist project for an integrated mind-body medicine), we first find Henricus Regius or Hendrik le Roy, a physician and Professor of Theoretical Medicine at the University of Utrecht, who was often called the 'first apostle of Cartesianism' (e.g. in the Nouvelles de la république des lettres in October 1686), asserting that the soul could be a mode of the body, with the body being understood as a machine, and that the human mind, inasmuch as it exists in a body, is organic (Regius 1646, 248, 246). Regius caused a celebrated scandal and brought much ideological discredit to his mentor Descartes, who had to deny any paternity of such ideas. But there could also be more concrete causes for worry: not just that physicians are proto-empiricists, or tend to view the soul-body relation in very 'sensory' terms, but also, that Descartes' consideration of particular mechanisms such as the heartbeat could have deflationary consequences on the nature and existence of the soul. Thus the Leuven theologian Libertus Fromondus, in his controversy with Descartes and Plempius over the heartbeat, felt, as Lucian Petrescu puts it, that if some of the operations normally attributed to the soul are presented as actually taking place as a result of the functioning of a mechanism, then we are in danger of explaining all operations of the soul, including its purely intellectual ones, through this mechanism. Reflecting on the causes of the heartbeat, Fromondus writes that Descartes' (mechanistic) approach "opens the way to the atheists, so that similar causes [motion provoked by heat] are assigned to the rational soul" (Fromondus' articles in reply to Descartes' Discourse and Essays, AT I 403, discussed in Petrescu $2013,419-420)$. However, the danger of atheism can come from anywhere: physics and cosmology, bedside medical practice, or armchair metaphysics. Of primary interest here is the question of the soul or mind (the reconfiguration of anima as mentis, which is occurring in this period, is part of the issue).

This question occupies center stage in the lecture given at Leiden in 1747 by Hieronymus Gaub, De regimine mentis quod medicorum est (translated in Rather 1965). Gaub had been Herman Boerhaave's student, and took over his Chair in Leiden. Here, Gaub suggests a clinical perspective on the problem of mind-body interaction (for he is speaking of mens rather than anima; Wright 2000, 249), in which the metaphysical distinction between mind and body is irrelevant. "Although the healing aspect of medicine properly looks toward the human body only, rather than the whole man, it does refer to a body closely united to a mind and, by virtue of their union, almost continually acting on its companion as well as being itself affected in turn" 
(Gaub 1747, in Rather 1965, 70, emphasis mine). Gaub refers to the authority of Descartes, "the most ingenious philosopher of his age," who "yielded to physicians" regarding the priority of medicine in these matters $(74)^{9}$, and states that due to the variability of temperaments, itself explainable in humoral (and hence medical) terms, the philosopher "cannot dispense with the aid of the physician" where the mind is concerned (86).

Interestingly, La Mettrie seems to have attended Gaub's lecture, some months prior to finishing L'Homme-Machine (Gaub mentions his presence), and spoke very favourably of it, carrying these ideas to what may seem (to us) their obvious materialist conclusion. Gaub did not appreciate La Mettrie's materialist appropriation of his ideas, and in 1763 included a short essay against himin his new edition of De regimine mentis (Rather 1965, 115-117), calling him "a little Frenchman" who produced a "repulsive offspring ... his mechanical man" (Gaub 1763, in Rather 1965, 115). More significantly, Gaub also denounced La Mettrie in a 1761 letter to Charles Bonnet (in Caraman 1859, 172), referring to the bad materialist usage of the "physics of the soul" undertaken by physicians. He worries that Bonnet's essay on the soul will have the same negative effect as La Mettrie's work, but concludes that this is not the case: the study of the "mechanism of the soul" (ibid.) need not entail materialism, since in Bonnet's case (and Gaub approves) it supports the claim that thought is not a mere "effect" of this mechanism. Gaub even begs Bonnet to publish an additional treatise on this topic, "so as to demonstrate that the mechanism of the operations of the soul is so far from favoring materialism, being instead the most convincing proof of the opposite system" (in Caraman 1859, 173). It must thus have been disturbing to Gaub that La Mettrie spoke so favourably about the ideas he heard at the 1747 lecture, not least since his enthusiasm makes sense: Gaub had defended the view that for the physician, the metaphysical distinction between mind and body is irrelevant. Faced with the consequences, Gaub has to demand in 1761 that someone of Bonnet's stature and scientific competence write a treatise to show that the naturalistic study of the "physics of the soul" (presumably some combination of psycho-physiology, psychology and of course the 'medicine of the mind') does not entail materialism.

The soul also undergoes a gradual process of naturalization in a medical context, in figures of Epicurean medicine such as the seventeenth-century physician Guillaume Lamy (Del Lucchese 2010). Here, anatomical arguments about body and soul are used in support of an anti-finalism, an Epicurean appeal to chance, and a more or less overt atheism. Guillaume Lamy (1644-1683) was a self-proclaimed Epicurean, a philosopher and physician based in Paris, who

\footnotetext{
${ }^{9}$ Gaub has in mind the passage from Part VI of Descartes' Discourse on Method where Descartes notes the interpenetration of mind and the organs of the body, so that medicine is the best way to render people wiser than they have hitherto been (AT VI, 62). In La Mettrie, this becomes: "medicine alone can change mind and behavior [les esprits et les mœurs] along with the body" (La Mettrie 1987, I, 67), and "the best philosophy is that of the doctors" (La Mettrie 1987, II, 36).
} 
published his major works between the late 1660s and the late 1670s. His first work, the 1669 De Principiis rerum, was an explicit piece of early modern Epicurean atomism, favouring Gassendi over Descartes (who was also viewed as a covert supporter of atomism), to show that Epicurus was right in the first place (although, in a gesture we will find often in works of this period, e.g. those of Cyrano de Bergerac as mentioned above, he also seeks to present these theories as complementary or compatible). He discusses atoms and the nature of matter at some length, hesitating as to which theory he finds most convincing, but we shall chiefly focus on his medical-materialist approach to the soul. In De Principiis (I, v) and in his later works, the Discours anatomiques $\left(1675,2^{\text {nd }}\right.$ revised edition 1679) and the Explication méchanique et physique des fonctions de l'âme sensitive (1677), he claims that the soul and animal spirits are actually identical. ${ }^{10}$

Lamy identifies the functions of the soul with (a) the nervous centres that receive impulses from external stimuli, and which ensure consciousness, ${ }^{11}$ and (b) the animal spirits which carry the "agitation" produced by the objects to the brain, which is the "source" or "reservoir" of the soul (Lamy 1996, 152-153), and then return to the heart, where they give rise to the passions, and to the muscles (which Lamy, following Galen, views as the instruments of voluntary motion); he says that the soul "flows" from the brain like rivers flowing through the "canals" of the nerves $(153,160,142)$. Lamy verbally still maintains a difference between the sensitive soul and the rational soul but ultimately locates all of these distinctions within a physiological frame (104f.). This idea that the soul is, in the end, a medical matter is prominently taken up by La Mettrie in his 1745 Histoire naturelle de l'âme (the revised version, which he entitled Traité de l'âme, appeared in 1750: see especially ch. VIII), but was also featured earlier in the century, in the famous anonymous, clandestine manuscript, Treatise of the Three Impostors (chapters XIX and XX) and later, in the article "Âme" of the Encyclopédie, in an atheist framework (Thomson 1992, Thomson 2008).

In the fascinating anonymous manuscript L'Âme Matérielle (The Material Soul), ${ }^{12}$ which can be dated to approximately 1725-1730 based on some of its citations, we witness a first, programmatic attempt at the naturalisation of mental phenomena, that is, at locating mental phenomena within an integrated corporeal and cognitive scheme (the distinction between these two levels being both anachronistic and irrelevant here). The text speaks explicitly of the "materiality of the soul" (Anon., 2003, 222). Thanks to Alain Niderst's research, we know that this text is an ingenious patchwork of Spinoza via Bayle (particularly his article "Buridan" in the Dictionnaire, the Pensées diverses sur la comète, but also the Réponse aux questions d'un

\footnotetext{
${ }^{10}$ Discours anatomiques, in Lamy 1996, 102, 105.

${ }^{11}$ Explication, in Lamy 1996, 142-143, 160-161.

12 Its modern editor, Alain Niderst, considers various possible candidates for authorship, which have evolved since his first edition of the work in the 1970s.
} 
provincial), Malebranche's psychophysiology, the doctrine of the (material) soul as a "fiery soul" from Gassendi as mediated through Bernier, Epicurean physiology (particularly borrowed from Guillaume Lamy), travel narratives, and various materialist prodromes from Lucretius to Vanini and Hobbes, typically using the analyses and summaries given in anti-materialist works. This means that the physiological portions of the work are based on older notions such as the "innate fire" in the soul, and animal spirits (which by the 1720s is no longer exactly state-of-theart neurophysiology), to which the author adds the idea of cerebral traces as a basis for memory and association.

L'Âme Matérielle uses the argument (which La Mettrie will expand on considerably, especially in L'Homme-Machine) that states of disease are evidence for the interaction of soul and body - and further, that they establish that both are composed of one and the same substance (Anon., 2003, 56), such that "the mind is subject to the law of all corporeal beings" (ibid.). We are also told in the last sentence of the treatise (236) that it is the "matter of which the brain is composed" that thinks. But even if the soul is material, the ontological status of this materiality is not generic: "The human soul is material, and is made up of the most subtle parts of the blood" (228). To use a distinction suggested by Wright (Wright 2000), but in a different sense from him, we can say that the soul as locus of mental activity is here being conceptualised both as substance - as a material substance subject to physical and biological laws - and as function - belonging to medicine in general and medicina mentis in particular. ${ }^{13}$ As Aram Vartanian put it, "if one conceives of the soul as the effect or function as certain structures of organised matter, it is inevitable that the more legitimate articulation of such a concept occurs through the progress of knowledge regarding anatomical structures themselves, and their modes of operation" (Vartanian 1982, 159-160).

From Regius and Gaub (on the one hand) to Lamy and L'Âme Matérielle (on the other hand), we witness one of the greatest fears described in the earlier part of this essay, come true: the materialization of the soul through its inscription, either in an actual medical set of concerns (most patent in Gaub), or in a complex combination of medical and metaphysical reflections, sometimes taking the form of a matter theory (Lamy), sometimes of a reductionist materialist program for reconfiguring mental properties as physical or corporeal properties (L'Âme Matérielle). One might ask, how medical is this, then?

I shall mention two features in which this radical medicine retains at the very least a strong rhetorical usage of the medical motif: the idea of a medicine of the mind (medicina mentis), which existed in different varieties, some more materialist than others, and that of a medicalization of morals, which is unambiguously a late-Epicurean radical project - with a surprising invocation of Machiavelli (La Mettrie has a satirical medical work entitled The Politics

${ }^{13}$ On the naturalisation of the soul as 'substance' or as 'function', see Vartanian 1982 and Wright 2000. 
of Machiavelli's Physician [La Mettrie 1746], which presents itself as the translation of a Chinese original, and in other related writings such as La Mettrie 1749-1750 he exploits at length the figure of the corrupt or deceitful physician as a 'Machiavellian'; as early as 1588, the surgeon John Read associates atheist physicians with Machiavellians: in his "Complaint of the abuse of the noble Arte of Chirurgerie," he deplores that some in his profession are "papists, nulli fidians, atheists temporizers, and some machiavells"; cit. Kocher 1947, 230). But these are, of course, rhetorics, not clinical or experimental medicine. When, at opposite ends of the ideological spectrum, a Thomas Browne or a La Mettrie invoke medical authority in their metaphysical pronouncements, it is just that: an authority argument - but, as I hope will be clear by the close of the essay, the radical medicine rhetoric may have had a certain productivity.

Medicine of the mind broadly can be distinguished into two strands: a non-reductionist (indeed, holist) project of a 'medicine of the whole man', e.g. in Erasmus: "Now the physician is concerned not only with the care of the body, the lower element in man, but with the treatment of the entire man, and just as the theologian takes the soul as his starting point, the physician begins with the body" (Erasmus 1989, 39-41; see Corneanu ms. 2013). But this nonreductionist version could also take the form of treatises of the passions (like Juan Luis Vives) or, explicitly, of a medicina mentis understood as a logic or pedagogy of the understanding (of a mixed Cartesian-Spinozist sort), as in Tschirnhaus' Medicina mentis et corporis (1695). ${ }^{14}$ Contrast this both with Gaub's project for a medical 'regimen of the mind' which would deal with "a body closely united to a mind and, by virtue of their union, almost continually acting on its companion as well as being itself affected in turn" (Gaub 1747, in Rather 1965, 70) and with the equally explicitly titled 1753 Médecine de l'esprit by the Paris physician Antoine Le Camus (which credits Gaub in its final pages, while also criticizing him for remaining too abstract "general axioms without practical consequences": Le Camus 1753, II, 335).

Le Camus notes that most people would not deny medicine's expertise when it comes to the body, but they would be reluctant to grant it authority over the mind, and he wants to remedy this situation; his program is indeed that "to remedy to the vices of the mind is nothing other than to remedy the vices of the body" (Le Camus 1753, I, 7). Le Camus's program for medicine holds that it is the science which has equal knowledge of mind and body, and hence can treat their "abstract combinations," and their "relations" (commerce). While terminologically he still refers to these as two substances, in practice he gives, e.g. an integrated account of "virtues" and "passions" as being as much part of body as they are of the soul (Le

\footnotetext{
${ }^{14}$ To be clear (and for more discussion see Corneanu, ms. 2013), treatises of the passions could be entirely nonmedical, like Cicero'sTusculan Disputations, III and IV; or strongly medically oriented, like Juan Huarte's Examen de ingenios para las sciencias (1575 - again a case of the influence of Galen's text on body and soul) but also late Renaissance humoral anthropologies such as Timothy Bright's 1586 Treatise of Melancholie (see Henry 1989 and Wright 2000), or - somewhere in between, like Descartes' Passions de l'âme (1649). I thank Sorana Corneanu for her help and many fruitful discussions on these topics.
} 
Camus 1753, I, 111f.; II, 239). Indeed, "God only excites ideas in our souls relative to the dispositions in our bodies" (ibid., I, ch. III, § 2, 49).

Here, medicine of the mind is a reductionist project (with a good deal of flexibility, depending on which states, processes, and organ systems are serving as the 'reducing theory'). It is neither purely medical nor purely philosophical: on the latter side, consider La Mettrie's statements - which themselves invoke the authority of the physician (both his own and that of more celebrated figures like Boerhaave, Haller and Gaub): "s/he who wishes to know the properties of the soul must first search for those which manifest themselves clearly in the body" (Traité de l'âme, ch. I, in La Mettrie 1987, I, 125: this is not an assertion that there is no such thing as the soul, but rather the advice to start with the body), or "The soul is just a pointless term of which we have no idea and which a good mind should only use to refer to that part of us which thinks" (L'Homme-Machine, in La Mettrie 1987, I, 98). In this case, soul is being reconstrued as a functional definition: it is neither eliminated in favour of a hypothetical 'basic physics' or the properties of matter in general, nor asserted as unique in its own right.

The more explicitly medical statements of a (reductionist) medicine of the mind, however, often extend beyond their province, whether accidentally or deliberately, as in the dismissive comment in Tarin's article "Physiologie" in the Encyclopédie: "If the body is healed, one need not worry about the soul" (XII, 1765, 538a). And we have already seen Ménuret, in the article "Mort," apparently granting the authority of theology ("The separation of the soul from the body ... is a theological dogma certified by religion, and consequently is uncontestable") but then immediately asserting the authority of "the lights of reason" and "medical observation," which entail in his view that the soul need not be further mentioned "in this purely medical article, in which we will restrict ourselves to describing the changes of the body, which, as they alone fall under the senses, can be grasped by the physicians" (Ménuret de Chambaud 1765/1966, 718b).

In either case, the soul is being reconfigured as a part of medico-natural discourse, and nothing more: it is "that part of us which thinks," for any additional, e.g. theological determinations have been naturalized. ${ }^{15}$ But none of these medical reconfigurations of soul (a.k.a. 'medicalization') are reducing it to size, shape and motion, or the functioning of pulleys, funnels and sieves; they are integrating the soul into an embodied framework. This implies conversely that the type of medicine at issue is, if not 'ensouled', at least somehow enhanced. The physician as atheist may be a dangerous character - including to morals - but this can only be true if this danger lies elsewhere than sheer physicalism or mechanism (yet another reason

\footnotetext{
${ }^{15}$ On the idea of a 'naturalisation of the mind' in the early radical Enlightenment which is not quite an elimination of mental or animate properties in favour of the basic properties of matter, but rather a bracketing-off of ontological considerations in order to treat mental faculties through their empirical manifestations, see Hatfield 1995 (e.g. 188).
} 
why Henry and Elmer's belief that the danger of atheism had nothing, or hardly anything to do with medicine, and was restricted to mechanism, is very strange indeed).

Diderot, in his late manuscript on 'physiology' and its conceptual ramifications, the Éléments de physiologie (unpublished in his lifetime; finished by the 1770s), imagines what he calls a "physical medicine": since "every sensation and every affection is corporeal, it follows that there is a physical medicine which is equally applicable to the body and the soul" (Diderot 1975-, vol. XVII, 512). It is not clear what exactly this "physical medicine" might be (Rey 2000b suggests it would be more organismic, less reductive), but it hints (as does Le Camus' book which lacks any philosophical sophistication) at the emergence of a scientific psychology - at a naturalisation of mental phenomena and beyond, which is both quantitative and experimental (looking at the role of poisons and hallucinogens, at the organic dimensions of mental illness, etc.), and at the same time squarely focused on an embodied solution. Why such a medicine might be expanded, and thereby also more of a danger, starts to become clear in other proclamations, by Diderot and La Mettrie notably (extending a tendency already present in Lamy and L'Âme Matérielle). Diderot asserts the primacy of medicine over both medicine and morals: "it is quite difficult to be a good metaphysician and a good moralist, without being an anatomist, a naturalist, a physiologist and a physician" (Réfutation d'Helvétius, in Diderot 1975-, XXIV, 555); referring to Locke, Diderot also wrote that "only he who has practiced medicine for a long time is entitled to write [works of] metaphysics" (Diderot 1765, 625b). Diderot's friend and executor Naigeon repeated this:

[Diderot] was rightfully convinced, and often repeated that only he who has practiced medicine for a long time is entitled to speak and write on metaphysics, because he alone has seen the phenomena: the body (machine) peaceful or furious, weak or strong, healthy or broken, raving or regulated, in turn moronic, enlightened, stupid, noisy, silent, lethargic, active, living and dead (Naigeon 1821: 217).

If the good moralist has to be a physician, we are no longer dealing just with a medicine of the mind or earlier types of medico-atheistic radicalism; we are dealing with a medicalization of morals.

The radical dimension of the figure I have been discussing here - not the 'physician of the soul' but the physicus sensualis, the animal incombustibile propter religionem - makes him (since it was inevitably a man) a different figure from the medical-materialist who ushers in the pose of scientific neutrality that is characteristic of early nineteenth-century medicine (as in Cabanis, or Claude Bernard, for whom "Physiology today is becoming an exact science, it must rid itself of the philosophical and theological ideas which for a long time were mingled with it"; Bernard 1878, I, 44. Cf. also Bernard 1937). 
Medicine can replace morals; it can serve as a reducing theory which will provide the constraints for a revised moral theory, as in La Mettrie or Diderot (a viewpoint already expressed in Gaultier's essentially unknown 1714 work, in the last chapter). La Mettrie creates a conceptual equivalence between médecin and moraliste: "It would doubtless be desirable for there to be only excellent Doctors to serve as Judges, for only they could distinguish the innocent criminal from the guilty one (L'Homme-Machine, in La Mettrie 1987, I, 91). That is, he deplores the fact that judgments of life and death are typically made without any knowledge of the physiological level of determination of action. The physician is the "only philosopher to whom her country should be grateful" (ibid., 62), also because, if we recall that the traditional task of philosophy is to meditate on life and death, the physician engages in this much more directly, "delivering certificates (brevets) of life and death" (La Mettrie 1747, 100). La Mettrie's medicalized morals does away with the dilemma of happiness and virtue by invoking 'deep structure', as opposed to a surface ethics, which relies on the dualism of body and soul. It is the deep structure of the man-machine, which is organic and follows the norm of health: "Of all kinds of happiness, I prefer that which develops with our organs, and seems to be more or less present, like strength, in all animate bodies" (Discours sur le Bonheur, in La Mettrie 1987, II, 247).

The medicalization of morals here takes on the form of radical hedonism, with potentially immoralist consequences (Wolfe 2009). But even here, the normative force of medical authority still makes itself felt. Even some twentieth-century scholars (e.g. Desné 1963, Rétat 1975 and more cautiously, Wellman 1992), faced with La Mettrie's potential immoralism and how closely it resembles that of his admirer, the Marquis de Sade, retort that La Mettrie was a physician, concerned with the overall physical and moral well-being of the organism, not someone preaching the destruction of a society's moral code. Nevertheless, there is something surprising in thus turning a thinker's professional status into a philosophical argument, and moreover, into a source of moral credibility.

III.

Focusing on the figure of the physician as atheist allows one to highlight some aspects of the interpenetration (or "cross-border traffic," in Michael Edwards' expression) of medicine and radical doctrines in early modern Europe, which are not otherwise immediately apparent. Notably, it shows that medicine played a role in debates on the soul, both in an earlier 'heterodox' context, such as the mortalists (Thomson 2008) and in later variations on either 'the material soul' (Wolfe and van Esveld, forthcoming), the medicine of the mind (in its postCartesian and Epicurean forms), or the medicalization of morals (an explicitly Epicurean project in La Mettrie: Wolfe 2009); thereby, it was mistaken of some scholars to claim that medicine 
played no role in metaphysical debates. Further, focusing on this figure brings to light a context in which the embodied, 'sensual physician' is neither subservient to natural theology, nor a waystation onto positive, experimental medicine of the nineteenth century.

Does this idea of the atheist physician, which clearly was culturally rich, have specifically philosophical consequences? Sometimes it is clear that the critics of the danger of atheism have in mind the problem of 'naturalism' in general. Recall John of Salisbury warning, in the twelfth century, that physicians placed "undue emphasis upon nature." The editor of a later edition of Browne's Religio Medici, Thomas Keck, observed more precisely that "The vulgar lay not the imputation of Atheism only upon Physicians, but upon Philosophers in general, who for that they give themselves to understand the operations of Nature, they calumniate them, as thought they rested in the second causes without any respect to the first" (cit. in Mothu 2010, 346n.). Resting on second causes is also what Bezançon described as the 'empiricist' danger of medicine, given the predilection of physicians to rely on "sensory causes" (Bezançon 1677, 339).

Yet the problem of naturalism, as Keck indicates, is not just that physicians have a dangerous tendency to place Hippocrates and Galen above Christ, or that their 'sensory practice' makes them de facto empiricists; the claim is also that they are 'naturalists' in the sense that they grant too much to the power of Nature rather than to God (Mersenne). ${ }^{16}$ In his attempt at a medical natural theology, Hecquet tries to rebut this kind of charge, asserting that even if Nature is appealed to by doctors and philosophers, it is not Nature in the sense of "what is merely material in objects," but rather a finalistic Nature understood as the work of the Creator, whose presence is evident "even in the least of man's organs" (Hecquet 1733, 279). Similarly Hecquet observes that the practice of the physician is not just a "practice" of design ("the contemplation of the wonders of the Creator in the design [ordonnance] of the parts of the human body is likely to increase the Faith of a Physician, to exercise and excite it") but also a meditation on death and hence on the 'ends' of man ("what is a better source of piety than the continual consideration of death, and the uninterrupted presence of the ultimate end of man"?) (Hecquet 1733, Preface, xlix-xli). Bezançon had argued earlier that medicine is, of all the sciences, that which most strongly reminds us of our frailty and finitude, and thereby brings us closer to God:

Far from Medicine leading us to atheism and libertinage, I argue on the contrary that of the natural sciences, there is none that elevates man to the knowledge of God more than Medicine. Nothing detaches us more from the creature, and carries us further to God, than the perfect knowledge of our own weakness and nothingness; nothing

\footnotetext{
${ }^{16}$ Mothu 2010 cites a variety of texts which criticize physicians for relying on 'secondary' rather than 'primary' causes.
} 
commits us more to consider another life, than the consideration of our death (Bezançon $1677,342-343)$.

But as I indicated above, my concern is not strictly with the 'danger' of the physician as atheist, or with arguments intended to rebut such charges (such as Hecquet's and Bezançon's above). It is also with the positive side of the issue, namely, the original intellectual outcomes produced by this figure. Perhaps chief among them is what I have termed the medicalization of the soul, in its post-Cartesian, Epicurean and otherwise materialist forms (from Regius and Lamy to Gaub and La Mettrie). This is of course not a self-consciously unified theoretical project. But, if earlier forms of medicina animi and medicina mentis were primarily intended as pedagogical emendations of the mind (whether of a Cartesian-Spinozist sort, like Tschirnhaus's Medicina mentis, or other), or aimed at 'the medicine of the whole man' rather than a reductionist project, this more materialistic medicalization of the soul (which can also appeal to Galen's Quod animi mores) seeks to integrate the soul into an embodied framework, the latter being chiefly specified by medicine. And this marks a difference between the 'negative' claim dating back at least to the Middle Ages (tres medici, duo athei) and the 'positive' claim emerging in the later seventeenth century: the latter seeks to articulate a new kind of knowledge, rather than just being purely destructive, what I called at the beginning of this essay, the emergence of a specifically medical body-soul problem. The latter allows for a new perspective on what we have come to call the 'mind-body' problem (whether by appealing to a concept of 'material soul', or more naturalistically, by insisting that the physician has the expertise to address such questions which were traditionally the bailiwick of metaphysics). This new perspective, in which the soul is embodied, opens onto a materialist medicine devoted to the organic fulfilment of our 'machine': "Our organs are capable of experiencing feelings or undergoing modifications which delight us and makes us love life" (La Mettrie, Discours sur le Bonheur, in La Mettrie 1987, II, 238). Worse even than Bezançon's fear of the physician as physicus sensualis, this brand of radical medicine, without being especially 'vitalist' in any technical sense, regularly insists on vitality, as opposed to "anatomie cadavérique": it is corporeal and hedonistic, a medicine for pleasure.

\section{References}

Bayle, Pierre. 1740. Dictionnaire historique et critique. Amsterdam: Libraires associés.

Bellis, Delphine. 2014. Empiricism Without Metaphysics: Regius' Cartesian Natural Philosophy. In M. Dobre and T. Nyden, eds., Cartesian Empiricisms, 151-183. Dordrecht: Springer. 
Bernard, Claude. 1878. Leçons sur les phénomènes de la vie communs aux animaux et aux végétaux, vol. I. Paris: Germer Baillière.

Bernard, Claude. 1937. Pensées, notes détachées, ed. L. Delhoume. Paris: Baillière.

Bernier, François. 1678. Abrégé de la philosophie de Mr. Gassendi, 8 vols. Lyon: Anisson et Possuel.

de Bezançon, Germain. 1677. Les médecins à la censure, ou, Entretiens sur la médecine. Paris: Louis Gontier.

Bright, Timothie. 1586. A Treatise of Melancholie: containing the causes thereof, and reasons of the strange effects it worketh in our minds and bodies.... London: Vautrollier.

Brockliss, Lawrence. 1989. The medico-religious universe of an early eighteenth-century Parisian doctor: the case of Philippe Hecquet. In The Medical Revolution of the Seventeenth Century, eds. R. French \& A. Wear, 191-221. Cambridge: Cambridge University Press.

Browne, Thomas. 1892. Religio Medici (1643), in Writings of Sir Thomas Browne, ed. D. Lloyd Roberts. London: David Stott.

Busson, H. 1948. La Religion des Classiques. Paris: PUF.

Caraman, A., Comte de. 1859. Charles Bonnet, philosophe et naturaliste. Sa vie et ses œuvres. Paris: A. Vaton.

Chaucer, Geoffrey. 1933. The Canterbury Tales. In The Complete Works of Chaucer, ed. F.N. Robinson. Boston: Houghton Mifflin.

Cicero. 1927. Tusculan Disputations, trans. J.E.King. Cambridge, Mass.: Harvard University Press. Conforti , Maria. 2007. Medicine, History and Religion in Naples in the Seventeenth and Eighteenth Centuries. In Medicine and Religion in Enlightenment Europe, eds. O.P. Grell and A. Cunningham, 63-78. Aldershot: Ashgate

Corneanu, Sorana. 2013 (ms.). The Care of the Whole Man: Medicine and Theology in the Late Renaissance.

Coward, William [Estibius Psychalethes]. 1702. Second Thoughts on the Human Soul. London: R. Basset.

Cranefield, P.F. 1970. On the origin of the phrase nihil est in intellectu. Journal of the history of medicine and allied sciences 25: 77-80. 
Cunningham, Andrew, Grell, Ole Peter, eds., 1996. Religio Medici: Medicine and Religion in Seventeenth-Century England. Aldershot: Scholar Press.

Del Lucchese, Filippo. 2010. Winged Men and the Cast of Dice: Anti-Finalism and Radical Materialism in Guillaume Lamy. Dialogue 49(4): 527-546

Desné, Roland. 1963. L’humanisme de La Mettrie. La Pensée 109: 93-110

Diderot, Denis. 1765. Locke. In D. Diderot and J. le Rond D’Alembert (eds.), Encyclopédie des arts et des métiers, IX, 625b-627a. Paris: Briasson (Reprint, Stuttgart/Bad Cannstatt: Frommann, 1966)

Diderot, Denis. 1975-. CEuvres complètes, eds. H. Dieckmann, J. Proust \& J. Varloot. Paris: Hermann.

Du Laurens, André. 1597. Discours de la conservation de la vue. Paris: J. Mettayer.

Dupuy, Jean-Pierre. 2000. The Mechanization of the Mind: On the Origins of Cognitive Science, trans. M.B. DeBevoise. Princeton: Princeton University Press.

Edwards, Michael. 2012. Body, Soul, and Anatomy in Late Aristotelian Psychology. In G. Manning, ed., Matter and Form in Early Modern Science and Philosophy, 33-75. Leiden: Brill.

Elmer, Peter. 2007. Medicine, Witchcraft and the Politics of Healing. In Medicine and Religion in Enlightenment Europe, eds. O.P. Grell and A. Cunningham, 223-241. Aldershot: Ashgate.

Erasmus. 1989. Oration in Praise of the Art of Medicine (1518), translated and annotated by Brian McGregor, in The Collected Works of Erasmus, vol. 29, eds. E. Fantham and E. Rummel with J. Ijsewijn, 31-50. Toronto: University of Toronto Press.

Garasse, François. 1623. La Doctrine curieuse des beaux esprits de ce temps ou prétendus tels. Paris: Sébastien Chappelet.

Garber, Dan. 1998. Soul and Mind: Life and Thought in the Seventeenth Century. In The Cambridge History of Seventeenth-Century Philosophy, eds. D. Garber and M. Ayers, vol. 1, 759795. Cambridge: Cambridge University Press.

Gaultier, Abraham. Parité de la vie et de la mort. La Réponse du médecin Gaultier (1714), ed. O. Bloch. Paris: Universitas / Oxford: Voltaire Foundation, 1993.

Hatfield, Gary. 1995. Remaking the Science of Mind: Psychology as Natural Science. In Inventing Human Science. Eighteenth-Century Domains, eds. C. Fox, R. Porter, R. Wokler, 184-231.

Berkeley: University of California Press. 
Hecquet, Philippe. 1733. La Médecine théologique. La Médecine créée, telle qu'elle se fait voir ici, sortie des mains de Dieu, 2 vols. Paris: G. Cavelier.

Henry, John. 1989. The Matter of Souls: Medical Theory and Theology in Seventeenth-Century England. In The Medical Revolution of the Seventeenth Century, eds. R.K. French and A. Wear, 87-113. Cambridge: Cambridge University Press.

Huarte de San Juan, J. 1989. Examen de ingenios para las sciencias (1575), ed. G. Serés. Madrid: Cátedra.

Iliffe, Rob. 1995. 'That Puzleing Problem': Isaac Newton and the Political Physiology of Self. Medical History 39: 433-458.

Israel, Jonathan. 2001. Radical Enlightenment. Philosophy and the Making of Modernity, 16501750. Oxford: Oxford University Press.

Israel, Jonathan. 2006. Enlightenment Contested. Oxford: Oxford University Press.

Israel, Jonathan. 2007. Enlightenment, Radical Enlightenment and the "Medical Revolution" of the Late Seventeenth and Eighteenth Centuries. In Medicine and Religion in Enlightenment Europe, eds. O.P. Grell and A. Cunningham, 5-28. Aldershot: Ashgate.

Jeannerod, Marc. 1985. The Brain Machine. The Development of Neurophysiological Thought, trans. D. Urion. Cambridge, Mass.: Harvard University Press.

Kocher, Paul H. 1947. The Physician as Atheist in Elisabethan England. The Huntington Library Quarterly 10(3): 229-249.

La Mettrie, Julien Offray de. 1746. Politique du médecin de Machiavel ou le chemin de la fortune ouvert aux médecins. Ouvrage réduit en forme de conseils par le Dr Fum Ho Ham, traduit sur l'original chinois par un nouveau maître es arts ... contient les portraits des plus célèbres médecins de Pékin. Amsterdam: n.d.

La Mettrie, Julien Offray de. 1747. La faculté vengée. Paris: Quillau.

La Mettrie, Julien Offray de. 1749-1750. L’Ouvrage de Pénélope ou Machiavel en médecine, "par Aletheius Demetrius." Berlin, 3 vols.

La Mettrie, Julien Offray de. 1960. L'Homme-Machine (1748), ed. A. Vartanian. Princeton : Princeton UP.

La Mettrie, Julien Offray de. 1987. CEuvres philosophiques, ed. F. Markovits, 2 vols. Paris: FayardCorpus.

La Mettrie, Julien Offray de. 2002. L'Ouvrage de Pénélope ou Machiavel en médecine (17491750). Berlin, 3 vols.; reprint in 1 volume, Paris: Fayard-Corpus. 
Lamy, Guillaume. 1996. Discours anatomiques. Explication méchanique et physique des fonctions de l'âme sensitive, ed. Anna Minerbi Belgrado. Paris: Universitas / Oxford: Voltaire Foundation.

Le Camus, Antoine. 1753. Médecine de l'esprit, où l'on traite des dispositions et des causes physiques qui sont des conséquences de l'union de l'âme avec le corps, influant sur les opérations de l'esprit; et des moyens de maîtriser ses opérations dans un bon état ou de les corriger quand elles sont viciées. Paris: Ganeau.

Mandeville, Bernard. 1730. A Treatise of the Hypochondriack and Hysterick Diseases, in Three Dialogues ( $1^{\text {st }}$ edition 1711$), 2^{\text {nd }}$ corrected edition. London: Tonson.

Ménuret de Chambaud, Jean-Joseph. 1765/1966. Mort (Médecine). In Encyclopédie ou Dictionnaire raisonné des arts et des métiers, eds. D. Diderot and J. Le Rond D'Alembert, X, 718727. Paris: Briasson, David, Le Breton \& Durand; reprint, Stuttgart/Bad Cannstatt: Frommann. Mersenne, Marin. 1624. L'Impiété des déistes, athées et libertins de ce temps, combatue et renversée de point en point par raisons tirées de la philosophie et de la théologie. Paris: P. Bilaine.

Mothu, Alain. 2010. Animal incombustibile. La rumeur du médecin athée. La Lettre clandestine 8: 317-358

Naigeon, J.-A. 1821. Mémoires historiques et philosophiques sur la vie et les ouvrages de D. Diderot. Paris: Brière.

Nutton, Vivian. 2001. God, Galen and the Depaganization of Ancient Medicine. In Medicine and Religion in the Middle Ages, eds. Peter Biller and Joseph Ziegler, 15-32. Woodbridge: York Medieval Press

Overton, Richard. 1968. Man's Mortality (1644). Amsterdam; reprint, ed. H. Fisch, Liverpool: Liverpool University Press.

Park, Katharine \& Daston, Lorraine. 1998. Wonders and the Order of Nature. New York: Zone Books/MIT.

Petrescu, Lucian. 2013. Descartes on the Heartbeat: The Leuven Affair. Perspectives on Science 21(4): 397-428.

Porter, Roy. 2001. Bodies Politic: Disease, Death and Doctors in Britain, 1650-1900. Ithaca: Cornell University Press. 
Rather, L.J. 1965. Mind and Body in Eighteenth-Century Medicine. A Study Based on J. Gaub's De regimine mentis. Berkeley: University of California Press.

Regius, Henricus. 1646. Fundamenta physices. Amsterdam: Elzevier.

Desné, Roland. 1963. L’humanisme de La Mettrie. La Pensée 109: 93-110

Rétat, Pierre. 1975. Le "cœur" de La Mettrie. In Mélanges de littérature française offerts à René Pintard, eds. N. Hepp, R. Mauzi and C. Pichois, 533-545. Strasbourg: Centre de Philologie et de Littératures Romanes.

Rey, Roselyne. 2000a. Naissance et développement du vitalisme. Oxford: Voltaire Foundation.

Rey, Roselyne. 2000b. Diderot and the Medicine of the Mind. In The Renewal of Materialism, ed. C.T. Wolfe, Graduate Faculty Philosophy Journal 22(1): 149-159

Smith, Justin E.H., ed. 2006. The problem of animal generation in early modern philosophy. Cambridge: Cambridge University Press.

Thomson, Ann. 1992. Guillaume Lamy et l'âme matérielle. Dix-huitième siècle 24: 63-71

Thomson, Ann. 2008. Bodies of Thought: Science, Religion, and the Soul in the Early Enlightenment. Oxford: Oxford University Press.

Wellman, Kathleen. 1992. La Mettrie: Medicine, Philosophy and Enlightenment. Durham: Duke University Press.

White, Andrew Dickson. 1898. A History of the Warfare of Science with Theology in Christendom, 2 vols. New York: Appleton and Co.

Willis, Thomas. 1681. A Medical-Philosophical Discourse of Fermentation; or, Of the Intestine Motion of Particles in Every Body (1659) and Of Feavers. trans. S. Pordage. London: Dring, Harper, Leigh, and Martin.

Willis, Thomas. 1684. An Essay of the Pathology of the Brain and Nervous Stock: In Which Convulsive Diseases are Treated of (translation of De Morbis Convulsivis), in Dr. Willis's Practice of Physick, trans. S. Pordage. London: T. Dring, C. Harper \& J. Leigh.

Wolfe, Charles T. 2004. 'Epicuro-Cartesianism': La Mettrie's Materialist Transformation of Early Modern Philosoph. In H. Hecht, Hrsg., La Mettrie. Ansichten und Einsichten, 75-95. Berlin: Berlin Wissenschafts-Verlag.

Wolfe, Charles T. 2009. A happiness fit for organic bodies: La Mettrie's medical Epicureanism. In Epicurus in the Enlightenment, eds. N. Leddy \& A. Lifschitz, 69-83. Oxford: Voltaire Foundation. 
Wolfe, Charles T. 2010. Empiricist heresies in early modern medical thought. In C.T. Wolfe \& O. Gal, eds. The Body as object and instrument of knowledge. Embodied empiricism in early modern science, 333-344. Dordrecht: Springer.

Wolfe, Charles T. 2014. Epigenesis as Spinozism in Diderot's biological project. In The Life Sciences in Early Modern Philosophy, eds. O. Nachtomy and J.E.H. Smith, 181-201. Oxford: Oxford University Press.

Wolfe, Charles T. and Terada, Motoichi. 2008. The animal economy as object and program in Montpellier vitalism. Science in Context 21(4): 537-579

Wolfe, Charles T. and van Esveld, Michaela. forthcoming 2014. The Material Soul: Strategies for Naturalising the Soul in an Early Modern Epicurean Context. In Conjunctions: Body, Soul and Mind from Plato to Descartes, ed. D. Kambaskovic. Dordrecht: Springer.

Wolfe, Charles T., Gal, Ofer, eds. 2010. The Body as object and instrument of knowledge. Embodied empiricism in early modern science. Dordrecht: Springer.

Wright, John P. 1991. Locke, Willis, and the Seventeenth-Century Epicurean Soul. In Atoms, Pneuma, and Tranquillity: Epicurean and Stoic Themes in European Thought, ed. M.J. Osler, 239258. Cambridge: Cambridge University Press.

Wright, John P. 2000. Substance vs. Function Dualism in Eighteenth-Century Medicine. In Psyche and Soma. Physicians and Metaphysicians on the Mind-Body Problem from Antiquity to the Enlightenment, eds. J.P. Wright \& P. Potter, 237-254. Oxford: Clarendon Press. 